\title{
Biochemical changes in cotton plants due to infestation by cotton mealybug Phenacoccus solenopsis Tinsley (Hemiptera: Pseudococcidae)
}

\author{
V. S. Nagrare*, J. Annie Sheeba, Paresh Bhoyar, Bhausaheb Naikwadi and Usha Satija \\ Central Institute for Cotton Research, P. B. No. 2, Shankar Nagar P. O., Nagpur- 440010 (Maharashtra), INDIA \\ *Corresponding author. E-mail: vs.nagrare@gmail.com
}

Received: June 12, 2016; Revised received: October 20, 2016; Accepted: February 5, 2017

\begin{abstract}
The study on biochemical changes in cotton plants (Gossypium hirsutum L.) due to infestation by cotton mealybug Phenacoccus solenopsis Tinsley (Hemiptera: Pseudococcidae) was conducted at CICR Nagpur during 2014-15. Total protein contents estimated from the shoots of the healthy plants $(4.29 \mathrm{mg} / \mathrm{g})$ indicated $50.5 \%$ increase over the healthy plants $(2.85 \mathrm{mg} / \mathrm{g})$. Total phenol content increased by $185.7 \%$ in the mealybug infested plants $(0.20 \mu \mathrm{g} / \mathrm{g})$ over the healthy plants $(0.07 \mu \mathrm{g} / \mathrm{g})$. Insignificant difference in the level of total soluble sugar was observed in mealybug infested plants $(1.00 \mu \mathrm{g} / \mathrm{g})$ as compared to healthy plants $(0.90 \mu \mathrm{g} / \mathrm{g})$. Total reducing sugar was found to be unaffected with the mealybug infestation. Although there was depletion in all the photosynthetic pigments viz., chlorophyll a (19.1\%), chlorophyll b (23.7\%), total chlorophyll $(21.2 \%)$ and carotenoids $(20.8 \%)$ due to the mealybug infestation, these values were not statistically different in the healthy plants. This is the first report on biochemical changes in cotton plant due to infestation of $P$. solenopsis.
\end{abstract}

Keywords: Biochemical changes, Cotton, Mealybug, Phenacoccus solenopsis

\section{INTRODUCTION}

Cotton is an important cash crop, grown extensively in different parts of the world. In India cotton is grown on 11.88 million ha with 35.2 million bales production (1bale $=170 \mathrm{~kg})(\mathrm{CCI}, 2016)$. Pest attack is the major biotic stress factor limiting plant growth and crop production in all the cotton growing areas of the world. The yield losses due to attack by insect pests can goes up to $60-70 \%$ of the potential yield of cotton if proper control measures are not taken up at appropriate time. In India, genetically modified cotton called 'Bt-cotton' occupies $95 \%(=11.28 \mathrm{~m} \mathrm{ha})$ of total cultivated area which offers good protection against three cotton bollworms, viz. American bollworm Helicoverpa armigera (Hubner), Spotted bollworm Earias insulana (Boisduvel), E. vittella (Fab.) and Pink bollworm Pectinophora gossypiella (Saunders). However, a sizable number of regular sucking pests including Jassid Amrasca biguttula biguttula (Ishida), Aphid Aphis gossypii Glover, Thrips Thrips tabaci Lind., Whitefly Bemisia tabaci (Gennadius) etc are dominant insect species damaging cotton crop. In the recent past 7 mealybug species of Hemiptera order infesting cotton have been identified. These are cotton mealybug Phenacoccus solenopsis Tinsley, papaya mealybug Paracoccus marginatus Williams and Granara de Willink, pink hibiscus mealybug Maconellicoccus hirsutus (Green), spherical mealybug Nipaecoccus viridis (Newstead), striped mealybug Ferrisia virgata Cockrell, mango mealybug Rastrococcus iceryoides
(Green) and ber mealybug Perissopneumon tamarin$d u s$ (Green). P. solenopsis is the predominant species in north and central India while $P$. marginatus in south India (Nagrare et al., 2013). Remaining species are of minor in nature and observed in traces distributed in three cotton growing zones of India.

Cotton mealybug, $P$. solenopsis is widespread and polyphagous pest, feeds on variety of crop plants worldwide and cause economic losses. Infestation of mealybugs on the cotton plant varies from different host plants. Mealybug nymphs and adults affect the aerial plant parts; mainly the shoots and leaves and suck sap from it. Cotton plants infested with $P$. solenopsis in the vegetative stage shows stem distortion, twisting and bushiness of the affected portion whereas in mature plants the infestation can be seen on the squares and bolls which greatly cause qualitative as well as quantitative losses. Mealybug infested cotton plants shows symptoms of distorted and bushy shoots, crinkled or twisted leaves, and in severe cases infested plants dries up completely resulting very low or no yield (Nagrare et al., 2013).

Plants are exposed to variety of biotic and abiotic stresses throughout their life among which biotic stress due to attack by insect pests is one of the greatest threats to plants that result in to substantial reduction in the potential yield (Sharma et al., 2003). The feeding of insects on plants induces biochemical and physiological changes in the host plants, affecting the life processes of host plants (Gomez et al., 2004). Plants 
respond to changes associated with insect feeding through various morphological, biochemical and molecular mechanisms. Accumulation of various compounds in accordance with the kind and degree of damage in the plant is to counter insect attack as defense mechanism (War et al., 2012; Punitahvalli et al., 2013). The defensive compounds are either produced constitutively or in response to plant damage and affect feeding, growth and survival of insects (War et al., 2012). The evolution of chemical defence in plants is linked to the emergence of chemical substances that are not involved in the essential photosynthetic and metabolic activities. These substances are secondary metabolites which are organic compounds that are not directly involved in the normal growth development or reproduction of organisms (Fraenkel, 1959) and often produced as by-products during the synthesis of primary metabolic products (Whittaker, 1970). Major known defence chemicals include plant secondary metabolites, protein inhibitors of insect digestive enzymes, proteases, lectins, amino acid deaminases and oxidases (Chen, 2008; Punithavalli et al., 2013).

Photosynthetic pigment in plant tissue is also one of the most important factors involve in the plant insect interaction. Insect feeding affect the process of photosynthesis. (Gomez et al., 2004) due to the alteration in the photosynthetic pigments. Thus, photosynthetic pigments like leaf chlorophyll content and carotenoids are the key parameters in the photosynthetic productivity gets altered during defensive responses against the attacking insect pest (Mao et al., 2007). However, there are scanty reports on biochemical changes in the cotton plants due to infestation by cotton mealybug $P$. solenopsis. Hence the present study was undertaken to understand the different levels of biochemical changes that occurs in the cotton plants (Gossypium hirsutum L.) infested with cotton mealybug $P$. solenopsis.

\section{MATERIALS AND METHODS}

Cotton plants (Gossypium hirsutum L.): Untreated seeds of cotton genotype RCH 2 (Bollgard II) were obtained from Rasi Seeds (P) Ltd. Coimbatore, Tamil
Nadu. Cotton plants were raised in the polythene bags containing soil and kept under natural climatic conditions. Care was taken to prevent from insect attack other than $P$. solenopsis on inoculation. Forty to 60 days plants were used for the study.

Culture of mealybug $\boldsymbol{P}$. solenopsis: The culture of P. solenopsis mass reared at temperature $27 \pm 2{ }^{\circ} \mathrm{C}$ and relative humidity $60 \pm 10 \%$ at Insectary and biocontrol laboratory of CICR Nagpur was released on the grown up seedlings. Two weeks after the release of mealybugs, shoots were taken for estimation of total soluble proteins $(\mathrm{mg} / \mathrm{g})$, total reducing sugars $(\mathrm{mg} / \mathrm{g})$, total soluble sugars $(\mu \mathrm{g} / \mathrm{g})$, total phenols $(\mu \mathrm{g} / \mathrm{g})$ while leaves were taken for chlorophyll estimation from both mealybug infested and healthy cotton.

Sample size: A replicated sample of shoots from different five cotton plants of infested and healthy plants blocks were harvested for the estimation of total soluble protein, total reducing sugars, total soluble sugars and total phenols. Similarly, leaves from top portion were harvested for estimation of photosynthetic pigments from each combination from the same location on the plant and with a similar orientation towards the light. The estimations of biochemicals in five replicates were done for each parameter.

\section{Biochemical estimation}

Total soluble proteins: Total soluble proteins were estimated according to the method of Lowery et al. (1951) with slight modification. Shoots (500 mg each) of mealybug infested and healthy cotton plants were taken and macerated in enzyme assay buffer and centrifuged at $10000 \mathrm{rpm}$ for 10 minutes. Supernatant $(0.4$ $\mathrm{ml}$ ) was mixed with alkaline copper sulphate solution $(4 \mathrm{ml})$ and then allowed to stand at room temperature for 10 minutes. Folins-ciocalteau phenol reagent $(0.4$ $\mathrm{ml}$ ) was added to the above reaction mixture and further allowed to incubate at room temperature for 30 mins; absorbance was measured at $660 \mathrm{~nm}$. A standard curve was prepared by using known concentration of bovine serum albumin. Protein content in both the types of samples were calculated through the standard calibrated curve of defined concentration of bovine

Table 1. Biochemical changes due to infestation of cotton mealybug P.solenopsis and healthy cotton plants G. hirsutum (Values are means of 5 observations of each parameter).

\begin{tabular}{|c|c|c|c|c|}
\hline \multirow{2}{*}{$\begin{array}{l}\text { Cotton genotype } \\
\text { RCH } 2 \text { Bollgard II }\end{array}$} & \multicolumn{4}{|c|}{$\begin{array}{l}\text { Plant biochemicals } \\
\end{array}$} \\
\hline & $\begin{array}{c}\text { Total soluble } \\
\text { protein }(\mathrm{mg} / \mathrm{g})\end{array}$ & $\begin{array}{c}\text { Total reducing } \\
\text { sugar }(\mathrm{mg} / \mathrm{g})\end{array}$ & $\begin{array}{l}\text { Total soluble } \\
\text { sugar }(\mu \mathrm{g} / \mathrm{g})\end{array}$ & $\begin{array}{l}\text { Total phenol con- } \\
\text { tents }(\mu \mathrm{g} / \mathrm{g})\end{array}$ \\
\hline Infested plant & $4.29 \pm 0.24$ & $3.36 \pm 0.14$ & $1.00 \pm 0.35$ & $0.20 \pm 0.03$ \\
\hline Healthy plant & $2.85 \pm 0.43$ & $3.37 \pm 0.09$ & $0.90 \pm 0.28$ & $0.07 \pm 0.01$ \\
\hline Student T test $(0.05)$ & 2.36 & NS & NS & 2.31 \\
\hline $\begin{array}{l}\text { Increase or decrease due to } \\
\text { mealybug infestation }\end{array}$ & +1.44 & -0.01 & +0.1 & +0.13 \\
\hline $\begin{array}{l}\text { Increase or Decrease }(\%) \\
\text { over healthy plant }\end{array}$ & $+50.5 \%$ & $-0.3 \%$ & $+11.1 \%$ & $185.7 \%$ \\
\hline
\end{tabular}

(+: increase, - : decrease in the content); \pm SEM; NS-Non significant 
Table 2. Alterations in photosynthetic pigments of the healthy and mealybug ( $P$. solenopsis Tinsley) infested cotton plant G. hirsutum (Values are means of 5 observations of each parameter).

\begin{tabular}{|c|c|c|c|c|}
\hline \multirow{2}{*}{$\begin{array}{l}\text { Cotton genotype } \\
\text { RCH } 2 \text { Bollgard II }\end{array}$} & \multicolumn{4}{|c|}{ Photosynthetic pigments } \\
\hline & $\begin{array}{c}\text { Chlorophyll a } \\
\mathrm{mg} / \mathrm{g}\end{array}$ & $\begin{array}{c}\text { Chlorophyll b } \\
\text { mg/g }\end{array}$ & $\begin{array}{c}\text { Total Chlorophyll } \\
\mathrm{mg} / \mathrm{g}\end{array}$ & $\begin{array}{c}\text { Carotenoids } \\
\mathrm{mg} / \mathrm{g}\end{array}$ \\
\hline Infested plant & $0.76 \pm 0.06$ & $0.29 \pm 0.02$ & $1.04 \pm 0.080$ & $0.28 \pm 0.025$ \\
\hline Healthy plant & $0.94 \pm 0.11$ & $0.38 \pm 0.06$ & $1.32 \pm 0.171$ & $0.34 \pm 0.05$ \\
\hline Student T test $(0.05)$ & NS & NS & NS & NS \\
\hline $\begin{array}{l}\text { Increase or } \\
\text { decrease due to mealybug } \\
\text { infestation }\end{array}$ & -0.18 & 0.09 & 0.28 & 0.07 \\
\hline $\begin{array}{l}\text { Increase or decrease }(\%) \\
\text { over healthy plant }\end{array}$ & $-19.1 \%$ & $-23.7 \%$ & $-21.2 \%$ & $-20.8 \%$ \\
\hline
\end{tabular}

\pm SEM, (+: increase, - : decrease in the content), NS-Non significant

serum albumin protein $(10-100 \mu \mathrm{g})$ and the total soluble protein content were calculated by the equation (1):

Total soluble protein $(\mathrm{mg} / \mathrm{g})=\begin{aligned} & \begin{array}{l}\text { Protein in sample } \\ \text { assessed }\end{array} \\ & \begin{array}{l}\text { Volume of sample } \\ \text { aliquot }\end{array}\end{aligned} \times \frac{\begin{array}{l}\text { Total volume } \\ \text { of extract }\end{array}}{\begin{array}{l}\text { Weight of plant tissue } \\ \text { sample used for assay }\end{array}} \times 100$

Total reducing sugars: Total reducing sugars were determined by following the method of Miller et al. (1972) with few modifications. Fresh shoots $(0.5 \mathrm{mg}$ each) of mealybug infested and healthy cotton plants were extracted using $5 \mathrm{ml}$ of hot $80 \%$ ethanol twice and the supernatant were collected and evaporated on water bath. To this, $10 \mathrm{ml}$ of distilled water added and sugars were allowed to dissolve completely. From this, $1.5 \mathrm{ml}$ of alcohol free extract was taken and the final volume made up to $3 \mathrm{ml}$ with distilled water. To this, 3 $\mathrm{ml}$ of dinitrosalicylic acid reagent was added and mixed gently. The reaction mixture was kept in boiling water bath for 5 minutes and allowed to develop colour. In this mixture $1 \mathrm{ml}$ of $40 \%$ Rochelle salts solution was added, the contents were mixed, cooled and the absorbance were measured at $510 \mathrm{~nm}$. The total reducing sugars of the unknown samples were calculated through the standard graph of glucose developed by the known concentrations of glucose $(100-500 \mu \mathrm{g})$ by following the above same equation as used in the determination of total protein content.

Total soluble sugars: Total soluble sugars were determined by the method of Hodge and Hofreiter (1962) with little alterations. Fresh shoot of mealybug infested and healthy cotton plants (250 mg each) hydrolyzed in $5 \mathrm{ml}$ of $2.5 \mathrm{~N} \mathrm{HCl}$ for 3 hours in water bath at 70-75 ${ }^{0} \mathrm{C}$. Contents were cooled to room temperature and neutralized with solid $\mathrm{Na}_{2} \mathrm{CO}_{3}$ till effervescence ceases and the supernatant was collected. Supernatant (200 $\mu \mathrm{l})$ was taken as sample to which $4 \mathrm{ml}$ anthrone was added; heated in boiling water bath for 10 minutes; cooled to room temperature and the absorbance was measured at $630 \mathrm{~nm}$. A standard graph was prepared by using known concentration of glucose to calculate the concentration of the sample.

Total phenols: Total phenols $(\mu \mathrm{g} / \mathrm{g})$ were determined by following the procedure of Malick and Singh (1980). Shoots of mealybug infested and healthy cotton plant $\left(500 \mathrm{mg}\right.$ each) were boiled at $70^{\circ} \mathrm{C}$ under water bath in $5 \mathrm{ml}$ ethanol $(80 \%)$ for 10 minutes. Cooled and macerated with $80 \%$ ethanol and centrifuged at 10,000 rpm for 5 minutes. Supernatant was allowed to dry under water bath. The residue was dissolved in $1 \mathrm{ml}$ of distilled water. To this $1 \mathrm{ml}$ of sample folin's ciocalteau reagent with $2 \mathrm{ml}$ of $20 \% \mathrm{Na}_{2} \mathrm{CO}_{3}$ solution was added and the total volume of reaction mixture was made up to $10 \mathrm{ml}$ with distilled water and the absorbance was measured at $650 \mathrm{~nm}$. A standard curve was prepared using 10-100 $\mu \mathrm{g}$ of catechol. From the standard curve, the concentrations of phenols in the unknown samples were calculated.

Photosynthetic pigments: Fresh leaves (250 mg each) were macerated in $80 \%$ acetone with mortar and pestle. The homogenate were filtered through the Whatman filter paper and the filtrate was collected. The absorbance of acetone extracts were measured at 645, 652, 663, 480 and $510 \mathrm{~nm}$ using UV- visible spectrophotometer. The chlorophyll a, b, total chlorophyll and total carotenoids were calculated following the equations (2, 3 \&4) of Arnon (1949) and equation (5) by Parsons et al. (1984). The photosynthetic pigments chlorophyll a, b, total chlorophyll and total carotenoids were estimated by macerating the fresh leaves $(250 \mathrm{mg}$ each) in $80 \%$ acetone under mortar and pestle. The homogenate were then filtered through Whatman filter paper and the filtrate was collected; the absorbance of acetone extracts were determined over 645, $652,663,480$ and $510 \mathrm{~nm}$ using UV- visible spectrophotometer.

Chlorophyll a: (22.9) x (O.D. 663) - (2.69 x O.D. 645)

Chlorophyll b: (22.9) x (O.D. 645) $\ldots \ldots \ldots \ldots \ldots \ldots . .(2)$

Total Chlorophyll: (20.2) x (O.D. 645) + (8.02) x (O.D. 663) 
Total Carotenoids content: (7.6) x (O.D. 480) - (1.49) x (O.D. 510)

Statistical Analysis: Statistical analysis of the data obtained from the different experiments was carried out according to the "Students T test" using online WASP (ICAR, Goa, India). Significant differences were established at $\mathrm{P}<0.05$. The data were also subjected to percentage changes (decrease or increase) in the infested and healthy leaves and calculated equation (6):

$\%$ increase or decrease $=\frac{\text { (Value of healthy plant }- \text { Value of infected plant) }}{\text { (Value of healthy plant ) }} \times 100$

\section{RESULTS AND DISCUSSION}

The results of the study clearly demonstrated that $P$. solenopsis infestation on cotton plant significantly increases $(\mathrm{P}<0.05)$ total soluble protein and total phenol contents while no significant change in the total reducing sugar and total soluble sugars. Insignificant reduction was observed in photosynthetic pigments viz., Chlorophyll a, Chlorophyll b, total chlorophyll and carotenoids observed.

Total soluble protein: The soluble total protein contents estimated from the shoots of the healthy and infested cotton plants showed significant difference $(\mathrm{P}<0.05)$. The soluble total protein contents increased as high as $50.5 \%$ in the mealybug infested plants (4.29 $\mathrm{mg} / \mathrm{g}$ ) over the healthy cotton plants $(2.85 \mathrm{mg} / \mathrm{g}$ ) (Table 1). Significant increase in soluble protein contents was observed by the infestation of $H$. armigera and A. craccivora in groundnut as compared to the control plants (War et al., 2013). Aphids Rhopalosiphum padi and Diuraphis noxia feeding caused significant increase of total protein contents in comparison with the control of leaves of four cereals viz., Russian wheat aphid, Diuraphis noxia-susceptible 'Arapahoe' and resistant 'Halt' wheat, D. noxia-susceptible 'Morex' barley, and $D$. noxia-resistant 'Border' oat (Ni et al., 2001). The total soluble proteins increased by $17.8 \%$ with infestation of pink hibiscus mealybug (Maconellicoccus hirsutus) on host plant (Terminalia arjuna) of tussar silkworm (Velide et al., 2013). These studies support present findings. The results are comparable with Chen et al. (2009) who stated that increase in protein content is a general phenomenon in plants in response to insect damage as defence mechanism.

When plants are under stress, protein based defencive compounds get accumulated in the plants (Chen et al., 2009) and this is an important and widely studied defence in plants against insect feeding and other stresses. Increase in defence related protein after mealybug infestation mediate a range of responses in plants that include inhibition of feeding, oviposition and survival of mealybugs. Similarly increased in defencive protein contents after insect infestation was also reported earlier in other crops (Ni et al., 2001; Sinha et al. 2005; Chen et al., 2009). In one isolated study, decrease in protein content was observed with Leaf folder (Cnaphalocrocis medinalis) infested rice genotypes (Punithavalli et al., 2013).

Total reducing sugars: Under present study, no significant change in total reducing sugars was observed in both the plants. (Table 1). The present results are not in conformity with the results that stated significant reduction in total reducing sugar with the infestation of leafroller (Diaphania pulverulentalis) (Narayanaswamy, 2003; Mahadeva and Nagaveni 2011), mealybug (M. hirsutus) (Bose et al., 1992) and jassid (Shree and Mahadeva 2005) in mulberry. Total reducing sugar was decreased by $64.9 \%$ by $M$. hirsutus in T. arjuna (Velide et al., 2013). Host variation and species infested might be the reason behind variation of reduction in total reducing sugars (Prasad et al., 2002; Mahadeva and Nagaveni, 2011, Mahadeva, 2016).

Total soluble sugars: The level of total soluble sugars was increased marginally by $11.1 \%$ in the mealybug infested plants $(1.00 \mu \mathrm{g} / \mathrm{g})$ but was not statistically significant with healthy cotton plants $(0.90 \mu \mathrm{g} / \mathrm{g})$ (Table 1). Similar increased in total soluble sugars by $31.3 \%$ was seen with the infestation of mealybug ( $M$. hirsutus) in T. arjuna (Velide et al., 2013). Contrarily, Mahadeva and Nagaveni (2011) indicated decreased in total reducing sugars in majority of the mulberry (Morus alba L) varieties due to the infestation by leafroller (Diaphania pulverulentalis Hampson). Lokeshwari and co-workers (2014) reported significant reduction in the amount of total soluble sugars in the shoots of mango plants upon varying levels of aphid (Aphis odinae) feeding. Total soluble sugars is one of the major components largely contributes to the total carbohydrate of plant and has proactive role in the synthesis of phenolic compounds, lectins, etc. as defence mechanism.

Total phenols: The infestation by $P$. solenopsis resulted in insignificant increase $(0.13 \mu \mathrm{g} / \mathrm{g})$ in the total phenol contents in the mealybug infested plants $(0.20 \mu \mathrm{g} /$ g) than the healthy cotton plants $(0.07 \mu \mathrm{g} / \mathrm{g})$. The resultant increase of the phenol contents due to mealybug infestation was registered as high as $185.7 \%$ (Table 1). Increase in phenol contents is common response of plant to counter the insect attack and inhibit the oviposition, population build up and continued existence of the attacking insect. It was observed that mealybug feeding has changed the phenol contents in the infested plants than the healthy cotton plants. It can be allied with the earlier finding (Hori et al., 1973) who observed increased phenol compound in the sugarbeets infested with lygus bug which inhibited the 
subsequent bug feeding. Usha Rani and Jyothsna (2009) observed that the extent of tissue damaged corresponds to the increased phenol concentration in response to attacking insect feeding. Infestation with $H$. armigera and $A$. craccivora resulted in a tremendous increase in the amounts of phenolic compounds than the uninfected plants of groundnut (War et al., 2013) and due to Leaf folder (Cnaphalocrocis medinalis) in rice (Punithavalli et al., 2013). Phenols involved in plant resistance against many biotic and abiotic stresses (Noreen and Ashraf 2009; Sharma et al., 2009; Usha Rani and Jyothsna 2010). The enhancement in the phenol contents in response to insect infestation is considered to be a general phenomenon (Ramiro et al., 2006; Sharma et al., 2009) as it reduces the growth and development of herbivores (Bhonwong et al., 2009; Sharma et al., 2009; Usha Rani and Jyothsna, 2010; War et al., 2011a; 2011b).

Photosynthetic pigments: Total photosynthetic pigments were estimated using leaf of the mealybug infested and healthy cotton plants. Decreased in the photosynthetic pigments including chlorophyll a, chlorophyll $b$, total chlorophyll and carotenoids due to the mealybug infestation were observed. The total chlorophyll content was decreased by $21.2 \%$ where as chlorophyll a and chlorophyll b was declined by $19.1 \%$ and $23.7 \%$ respectively in the mealybug infested cotton plants than healthy cotton plants. Carotenoids found to be reduced by $20.8 \%$. Though there was decreased in the photosynthetic pigments in infested plants, the difference in pigments between the infested and healthy cotton plant was found to be nonsignificant (Table 2). The reduction in chlorophyll content with $P$. solenopsis infestation was also reported in tomato (Huang et al., 2013). Reduction in photosynthetic pigments with the infestation of Leaf roller (D. pulverulentalis) was also observed in mulberry (Mahadeva and Nagaveni 2011). Total chlorophyll, chlorophyll-a, and chlorophyll-b and carotenoids were reduced significantly by $45.4,45.941 .9 \%$ and $44.9 \%$, respectively with the infestation of $M$. hirsutus in $T$. arjuna, which corroborate the findings of the present study (Velide et al., 2013).

The results clearly demonstrated that infestation of $P$. solenopsis had negative impact on chlorophyll and carotenoid contents of the plants. The present study revealed that the concentration of photosynthetic pigments including total chlorophyll, chlorophyll a, chlorophyll $b$ and carotenoids contents are relatively higher in the non-infested leaves of cotton plant compared to the mealybug infested plants. These results are in line with the earlier findings (Golawska et al., 2010) that revealed higher chlorophyll concentrations in noninfested plant.

The present findings are also relatively similar with the results of Huang and coworkers (2014) who have explained the reduction in chlorophyll content resulted in response to the feeding damage caused by hemipteran insect Bagrada hilaris. It is also considered that the transition of the photosynthetic pigment can also be due to the adaptive reactions against the insect attack (Golawaska et al., 2010). Infestation by Thrips tabaci (Linderman) on Hypericum sampsoni Hance (Dai et al., 2009) and tomato (Buntin et al., 1993) apparently synthesised less chlorophyll pigment in damaged leaves. Total chlorophyll and carotenoid concentrations differed among Betta wheat isolines in response to aphid feeding (Heng-Moss et al., 2003). The level of photosynthetic pigment like chlorophyll and carotenoids contents of plant in response to the insect attack is mainly determined by the species of host plant and scale of insect abundance. However it can also get influenced with respect to the environmental factors (Mary et al., 2006). The changes in the chlorophyll content in the stress leaves due to less synthesis might be part of adaptive response of plant (Golawska et al., 2010). Insect injury has indirect effects on the growth and performance of host plants through photosynthetic suppression, causes uncertain reduction in photosynthesis, which likely depends on the degree of infestation (Huang et al., 2013).

\section{Conclusion}

The study demonstrated occurrence of biochemical changes due to $P$. solenopsis infestation in cotton plants. Cotton plants responded to biochemical changes associated with feeding of $P$. solenopsis, through the accumulation of phenol (185.7\%) and protein (50.5\%) contents as defensive mechanism. Losses of the photosynthetic pigments in response to $P$. solenopsis suggest a feeding-induced stress response in the host plants. Thus, the present study provides a better understanding of defensive mechanism by biochemical changes due to the impacts of $P$. solenopsis infestation in cotton.

\section{ACKNOWLEDGEMENTS}

Research facilities provided by the Head, Crop Protection Division and Director CICR, Nagpur are duly acknowledged. We also acknowledge funding by Agriculture Department, Government of Maharashtra through Crop Pest Surveillance and Advisory Project (CROPSAP) in Maharashtra.

\section{REFERENCES}

Arnon, D. I. (1949). Copper enzymes in isolated chloroplasts. Polyphenyl oxidase in Beta vulgaris. Plant Physiol., 24:1-15.

Bhonwong, A., Stout, M. J., Attajarusit, J. and Tantasawat, P. (2009). Defensive role of tomato polyphenol oxidases against cotton bollworm (Helicoverpa armigera) and beet armyworm (Spodoptera exigua). J. Chem. Ecol., 35:28-38

Bose, P. C., Majumdar, S. K. and Senguptha, K. (1992). Effect of tukra disease on the nutritional composition of 
mulberry (Morus alba L.). Sericologia, 32: 311-316

Buntin, G.D., Gilbertz, D.A. and Oetting, R.D. (1993). Chlorophyll loss and gas exchange in tomato leaves after feeding injury by Bemisia tabaci (Homoptera: Aleyrodidae). J. Econ. Entomol., 86:517-22

CCI. (2016). Cotton Corporation of India, Ministry of textile, Government of India available at http:// www.cotcorp.gov.in/national-cotton.aspx.

Chen, M. S. (2008). Inducible direct plant defence against insect herbivores: A review. Insect Science, 15:101-114

Chen, Y., Ni, X. and Buntin, G.D. (2009). Physiological, nutritional and biochemical bases of corn resistance to foliage-feeding fall Armyworm. J. Chem Ecol., 35:297306

Dai, Y., Shao, M., Hannaway, D., Wang, L., Liang, J., Hu, L. and Lu, H. (2009) Effect of Thrips tabaci on anatomical features, photosynthetic characteristics and chlorophyll fluorescence of Hypericum sampsonii leaves. Crop Prot., 28:327-332

Fraenkel, G. (1959). The raison detre of secondary plant substances. Science, 129 (3361): 1466-70

Golawska, S., Krzy, Zanowski, R. and Lukasik, I. (2010). Relationship between infestation and chlorophyll content in Fabaceae species. Acta Biol. Crac. Ser. Bot., 52: 76-80

Gomez, K. S., Oosterhuis, D. M., Rajguru, S. N. and Johnson, D. R. (2004). Molecular biology and physiology. Foliar antioxidant enzyme responses in cotton after aphid herbivory. J. Cotton Sci., 8: 99-104

Heng-Moss, T. M., Ni, X., Macedo, T., Markwell, J. P., Baxendale, F. P., Quisenberry, S. S. and Tolmay, V. (2003). Comparison of chlorophyll and carotenoid concentrations among Russian wheat aphid (Homoptera: Aphididae)-infested wheat isolines. J. Econ. Entomol., 96:475-481

Hodge, J.E. and Hofreiter, B.T. (1962). In: Methods in carbohydrate chemistry (eds Whistler, R.L and BeMiller, J.N.), Academic Press, New York.

Hori, K. (1973). Studies on feeding habits of Lygus disponsi Lannavuori (Hemiptera : Miridae) and the injury to host plant: III. Phenolic compounds, acid phosphatase and oxidative enzymes in the injured tissue of sugar beef leaf. Appl. Ent. Zool., 8: 103-112

Huang, J., Zhang, P. J., Zhang, J., Lu, Y. B., Huang, F. and Li, M. J. (2013). Chlorophyll content and chlorophyll fluorescence in tomato leaves infested with an invasive Mealybug, Phenacoccus solenopsis (Hemiptera: Pseudococcidae). Environ. Entomol., 42(5):973-979

Huang, T. I., Reed, D. A., Perring, T. M., Palumbo, J. C. (2014). Feeding damage by Bagrada hilaris (Hemiptera: Pentatomidae) and impact on growth and chlorophyll content of Brassicaceous plant species. Arthropod-Plant Interact, doi:10.1007/s11829-0149289-0

Lokeshwari, D., Verghese, A., Shivashankar, S., Krishna Kumar, N. K., Manjunatha, H. and Venugopalan, R. (2014). Effect of Aphis odinae (Hemiptera: Aphididae) infestation on sugars and Amino acid content in mango. African Entomology, 22(4):823-827

Lowery, O. H., Rosebrough, N. J., Farr, A. L. and Randall, R. J. (1951). Protein measurement with the folin phenol reagent. J. Biol. Chem., 193:265-275

Mahadeva, A. and Nagaveni, V. (2011). Alterations in the biochemical components and photosynthetic pigments of mulberry (Morus Spp.) attacked by leaf roller (Diaphania pulverulentalis) pest. African Journal of Biochemistry Research, 5(14): 365-372

Mahadeva, A. (2016). An Investigation on changes in biochemical contents in Mealybugs infested Mulberry foliage. Journal of Plant Science \& Research, 3 (2): 1-5

Malick, C. P. and Singh, M. B. (1980). In: Plant Enzymology and Histoenzymology, Kalyani Publications, New Delhi, p. 286.

Mao. L.Z., Lu, H.F., Wang, Q. and Cai, M.M. (2007). Comparative photosynthesis characteristics of Calycanthus chinensis and Chimonanthus praecox. Photosynthetica, 45:601-605

Mary, E. P., Maria, R. and Paymon, A. (2006). Response of photosynthesis to high light and drought for Arabidopsis thaliana grown under a UV-B enhanced light regime. Photosynth. Res., 90:79-90

Miller, G. L. (1972). Use of dinitrosalicyuclic acid reagent for determination of reducing sugars. Anal. Chem., 31: 426- 428

Nagrare, V. S., Kranthi, S., Kranthi, K. R., Naik, V. C. B., Kumar, R., Dharajothi, B., Udikeri, S. S., Mukherjee, A. K., Mukherjee, P. K., Monga, D., Sampath Kumar, A., Narkhedkar, N. G., Banu, Gulsar, Raju, A. R., Tayade, A.S., Prakash, A. H. and Khader, SESA. (2013). Handbook of Cotton Plant Health, Central Institute for Cotton Research, Nagpur pp: 100

Narayanaswamy, K. C. (2003). Biochemical composition of leaf roller infested mulberry leaf. Insect Environ., 8(4): 166-167

Ni, X., Quisenberry, S. S., Heng-Moss, T., Markwell, J., Sarath, G., Klucas, R. and Baxendale, F. (2001). Oxidative responses of resistant and susceptible cereal leaves to symptomatic and non-symptomatic cereal aphid (Hemiptera: Aphididae) feeding. J. Econ. Entomol., 94:743-751

Noreen, Z. and Ashraf, M. (2009). Change in antioxidant enzymes and some key metabolites in some genetically diverse cultivars of radish (Raphanus sativus L.). Environ. Exp. Bot., 67:395-402. doi: 10.1016/j.envexpbot. 2009.05.011

Parsons, T. R., Maita, Y. and Lalli, C. M. (1984). Oxford: Pergamon;. A manual of chemical and biological methods for seawater analysis.

Prasad, S. K., Sreedhar, S., Singhvi, N. R., Kodandaramaiah, J., Sen, A.K. (2002) Post biochemical changes in thrips infested leaves of mulberry (Morus spp.). Plant Archives, 2:85-88

Punithavalli, M., Muthukrishnan, N. M. and Balaji Rajkuma, M. (2013). Defensive responses of rice genotypes for resistance against rice Leaf-folder Cnaphalocrocis medinalis. Rice Science, 20(5):363-370

Ramiro, D. A., Guerreiro-Filho, O. and Mazzafera, P. (2006). Phenol contents, oxidase activities and the resistance of coffee to the leaf miner Leucoptera coffeella. J. Chem. Ecol., 32:1977-88. doi: 10.1007/s10886 -006-9122-z

Sharma, H. C., Pampathy, G., Dwivedi, S. L. and Reddy, L. J. (2003). Mechanism and diversity of resistance to insect pests in wild relatives of groundnut. $J$ Econ Entomol. 96:1886-97. doi: 10.1603/0022-049396.6.1886 
Sharma, H.C., Sujana, G. and Rao, D.M. (2009). Morphological and chemical components of resistance to pod borer, Helicoverpa armigera in wild relatives of pigeonpea. Arthropod-Plant Interact., 3:151-61. doi: 10.1007/ s11829-009-9068-5

Shree, M.P. and Mahadeva, A. (2005). Impact of jassids (Empoasca flavescens F.) infestation on the biochemical constituents and photosynthetic pigments of mulberry (Morus spp.) foliage. National seminar on "Scenario of Sericulture in India". 25th - 26th March. Sri Padmavathi Mahila Visvavidyalayam, Thirupathi, Andhra Pradesh, p. 13.

Sinha, S., Balsaraswathi, R., Selvaraju, K. and Shanmungasundaram, P. (2005). Molecular and biochemical markers associated with leaffolder (Cnaphalocrocis medinalis G.) resistance in rice (Oryza sativa L.). Ind. J. Biochem. Biophys., 42: 228-232.

Usha Rani, P. and Jyothsna, Y. (2009). Physiological changes in the groundnut, Arachis hypogaea L. plant due to the infection of a fungal pathogen, Cercosporidium personatum Deighton. Allelopathy J., 23(2): 369-378

Usha Rani, P. and Jyothsna, Y. (2010). Biochemical and enzymatic changes in rice as a mechanism of defense.
Acta Physiol. Plant., 32:695-701. doi: 10.1007/s11738009-0449-2

Velide, L., Cheruvuand, S. and Donthula, S. (2013). Studies on biochemical components, secondary metabolites and photosynthetic pigments in Mealybug infected Terminalia arjuna-a primary host plant of Tasar Silkworm Anthereae mylitta drury. Helix, 2: 297-300

War, A.R., Paulraj, M.G., Ahmad, T., Buhroo, A.A., Hussain, B., Ignacimuthu, S. and Sharma, H. C. (2012). Mechanisms of plant defence against insect herbivores. Plant Signaling \& Behavior, 7(10): 1306-1320

War, A. R., Paulraj, M.G., Ignacimuthu, S. and Sharma, H. C. (2013). Defensive responses in groundnut against chewing and sap-sucking insects. Journal of Plant Growth Regulation, 32 (2): 259-272 DOI: http:// dx.doi.org/10.1007/s00344-012-9294-4

War, A. R., Paulraj, M.G., War, M.Y. and Ignacimuthu, S. (2011a). Jasmonic acid mediated induced resistance in groundnut (Arachis hypogaea L.) against Helicoverpa armigera (Hubner) (Lepidoptera: Noctuidae). Journal of Plant Growth Regulation, 30:512-523

War, A. R., Paulraj, M.G., War, M.Y., Ignacimuthu, S. (2011b). Differential defensive response of groundnut 